\title{
Peningkatan Pengetahuan Masyarakat Jemaah Mesjid Ulil Amri Tentang Pencegahan Dan Penanganan Diare Di Tingkat Rumah Tangga
}

\author{
Rahmawati*, Hasnah, Effendy Rasiyanto \\ Teknologi Laboratorium Medis, Politeknik Kesehatan Muhammadiyah Makassar \\ *E-mail: rahmawatiamma60@gmail.com
}

\begin{abstract}
Diarrhea can be prevented in various ways, including treating patients, providing health education about hygiene, and personal and environmental hygiene including water sources, trash cans, and disposal offeces. One of the efforts to prevent diarrheal disease is to provide counseling on diarrheal diseases. The selection of community service locations in Manggala Village, Manggala District, Makassar City, especially the Ulil Amri mosque congregation because the community, especially mothers do not have sufficient knowledge about proper hand washing, people who are not used to it. washing hands in every activity, and the community still lacks knowledge about diarrheal disease, its handling and prevention. Counseling in the context of community service is important because it can communicate information and materials about the dangers and possibilities of preventing diarrheal disease and protecting oneself, the community, and the environment from the spread of disease. Increasing public knowledge through counseling and demonstrations has shown very good results. The community was very enthusiastic about the material provided, the community was active in the question and answer session by seeing the many questions, opinions and experiences they issued that could be used to prevent and overcome diarrheal diseases and maintain environmental health.
\end{abstract}

Keywords: Increased knowledge, prevention and management of diarrhea, household level

\begin{abstract}
Abstrak
Diare dapat dicegah dengan berbagai cara, termasuk mengobati pasien, memberikan pendidikan kesehatan tentang kebersihan, dan kebersihan pribadi dan lingkungan termasuk sumber air, tempat sampah, dan pembuangan tinja. Salah satu upaya pencegahan penyakit diare adalah dengan memberikan penyuluhan penyakit diare.Pemilihan lokasi pengabdian masyarakat di Kelurahan Manggala Kecamatan Manggala Kota Makassar khususnya jemaah mesjid Ulil Amri karena masyarakat khususnya ibu-ibu belum memiliki pengetahuan yang cukup tentang cuci tangan yang benar, masyarakat yang belum terbiasa mencuci tangan dalam setiap kegiatan, dan masyarakat masih kurang memiliki pengetahuan tentang penyakit diare, penanganan dan pencegahannya. Penyuluhan dalam rangka melakukan pengabdian masyarakat penting karena dapat mengkomunikasikan informasi dan materi tentang bahaya dan kemungkinan pencegahan penyakit diare dan melindungi diri sendiri, masyarakat, dan lingkungan dari penyebaran penyakit. Peningkatan pengetahuan masyarakat melalui penyuluhan dan demonstrasi menunjukkan hasil yang sangat baik. Masyarakat sangat antusias dengan materi yang diberikan, masyarakat yang aktif dalam sesi tanya jawab dengan melihat banyak pertanyaan, pendapat dan pengalaman yang mereka keluarkan yang dapat digunakan untuk mencegah dan mengatasi penyakit diare serta menjaga kesehatan lingkungan.
\end{abstract}

Kata kunci: Peningkatan pengetahuan, pencegahan dan penanganan diare, tingkat rumah tangga 


\section{PENDAHULUAN}

Diare di Indonesia tetap merupakan penyakit endemik dan seringkali sering menyebabkan peristiwa luar biasa (KLB) di masyarakat. Diare dapat didefinisikan sebagai peningkatan jumlah buang air besar lebih dari 3 kali sehari. Diare dapat menyebabkan kekurangan cairan dan elektrolit, dan jika tidak ditangani dengan baik, diare yang parah dapat menyebabkan kematian. Hampir semua wilayah geografis dan orang-orang dari segala usia di dunia terkena diare, tetapi angka kematian bayi dan anak tinggi, yang dapat menyebabkan penyakit serius.

Diare dapat disebabkan oleh kadar air dan elektrolit yang tidak normal di usus. Sekitar 500 juta anak di seluruh dunia menderita diare setiap tahun, dan sekitar 20 dari semua kematian anak di negara berkembang terkait dengan diare dan dehidrasi. Gangguan jurnal dapat mengenai lambung dan usus (gastroenteritis), usus halus (enteritis), usus besar (Colite) atau usus besar dan usus besar (Enterocolith) (Wong, 2008).

Menurut Survei Kesehatan (SKRT) Penelitian Kematian dan Kesehatan Dasar tahun ini, diketahui bahwa diare masih menjadi pembunuh nomor satu anak-anak di Indonesia. Penyebab utama kematian akibat diare adalah manajemen rumah tangga dan fasilitas sanitasi yang tidak memadai (Kemenkes RI, 2011).

Salah satu cara mencegah dehidrasi pada anak diare bisa dimulai dengan larutan gula di rumah. Berikan larutan gula dalam garam untuk menggantikan cairan tubuh dan elektrolit yang terbuang akibat diare. Meskipun air sangat penting untuk mencegah dehidrasi, air minum normal tidak mengandung garam dan elektrolit yang diperlukan untuk menjaga keseimbangan elektrolit dalam tubuh, sehingga larutan gula lebih disukai. Campuran garam glukosa yang terkandung dalam larutan gula dapat diserap sepenuhnya oleh saluran usus diare. Meskipun lebih dari $90 \%$ ibu mengetahui tentang larutan gula, hanya 22\% anak diare yang mendapatkan larutan gula garam (Kemenkes RI, 2011).

Pencegahan penyakit diare dapat dibuat untuk berbagai cara, termasuk pengobatan untuk pasien, pendidikan kesehatan kesehatan, baik kebersihan individu dan sanitasi, termasuk sumber air, kaleng sampah, penghapusan tinja juga, faktor pemberantasan lalat dan kecoak dapat bertindak sebagai operator mekanis. (Rusmartini, 2009; Rina, 2017, Soetanto dkk, 2011; Maryatun, 2008, Vivancos et al., 2018).

Pemilihan lokasi pengabdian masyarakat di Kelurahan Manggala Kecamatan Manggala Kota Makassar khususnya jemaah mesjid Ulil Amri karena rendahnya pengetahuan warga, khususnya ibu mencuci tangan kanan, dari komunitas juga tidak terbiasa mencuci tangan. Masih belum ada kekurangan aktivitas dan pengetahuan masyarakat tentang penyakit diarreast, guru dan pencegahan.

Sebagian besar penduduk masih memiliki sampah di mana-mana dan tidak adanya lokasi pengolahan limbah akhir. Kondisi dan perilaku masyarakat adalah masalah bagi dunia kesehatan karena dapat memfasilitasi pengembangan semua penyakit, terutama penyakit menular. Salah satu dari banyak penyakit menular dan dampak berbahaya adalah diare. Penyakit ini memiliki peningkatan jumlah pasien yang berada di musim hujan karena kondisi air telah menjadi pasangan. Kasus kejadian celana lingkungan juga tidak dapat dipisahkan dari kurangnya struktur untuk fasilitas kesehatan lingkungan di sekitar masjid Amri Ulil, seperti air minum dan saluran pembuangan.

Perilaku tidak sehat di masyarakat dapat disebabkan oleh kurangnya pemahaman masyarakat tentang masalah kesehatan. Oleh karena itu, diperlukan upaya untuk memperluas pengetahuan guna mengubah persepsi dan meningkatkan kesadaran masyarakat akan lingkungan yang sehat yang dapat mempengaruhi penurunan angka diare.

Upaya untuk mencegah diare dilakukan melalui konsultasi diare. Penasihat Kesehatan adalah kegiatan atau upaya untuk mengirim pesan kesehatan kepada masyarakat, sehingga harus mendapatkan pengetahuan kesehatan yang lebih baik. Pengetahuan yang diperoleh akhirnya direncanakan untuk mempengaruhi perilaku. Oleh karena itu, kegiatan konsultasi harus memiliki dampak perubahan dalam perilaku target (Notatmodjo, 2010). Konsultasi diare adalah cara untuk menyebarluaskan informasi tentang penyakit diarroelee yang bertujuan untuk mengetahui pencegahan pencegahan diare, kemudian dipraktikkan dalam kehidupan sehari-hari sehingga dapat mengurangi kejadian diare.

Jumlah pasien dengan diare meningkat sehingga sangat penting untuk meningkatkan pengetahuan dan keterampilan masyarakat dalam deteksi dini, melalui semakin banyak pengetahuan tentang bahaya penyakit diare. Aktivitas layanan ini bertujuan untuk meningkatkan pengetahuan komunitas masjid Ulil Amri tentang bahaya diare. 
Berdasarkan uraian diatas dan informasi tentang penyakit diare, maka perlu adanya upaya peningkatan pengetahuan dan ketrampilan di tingkat rumah tangga jemaah Mesjid Ulil Amri dalam pendeteksian dini penyakit diare di Kelurahan Manggala Kecamatan Manggala Kota Makassar.

\section{METODE}

Sasaran kegiatan ini adalah para orang tua jamaah Masjid Ullil Amri yang berjumlah 25 orang. Dalam kegiatan ini terdapat 5 orang mahasiswa yang ikut serta dengan tujuansebagai sarana bagi mahasiswa untuk belajar hidup bermasyarakat dan memahami masalah kesehatan dan upaya preventif.

Dalam pelaksanaan pengabdian masyarakat menggunakan dua metode sebagai berikut:

a. Metode presentasi dan diskusi. Tujuan dari metode ini adalah untuk memberikan informasi dan materi tentang bahaya dan cara pencegahan diare dan melindungi diri sendiri, masyarakat, dan lingkungan dari penyebaran penyakit. Metode ini juga menggunakan Infocus dan laptop untuk menjelaskan materi yang akan disampaikan dalam format PowerPoint, dengan gambar-gambar penyakit diare. Materi yang diberikan dalam konsultasi adalah:

1) Informasi tentang pengertian diare

2) Informasi tentang gejala diare

3) Informasi tentang penyebab diare

4) Informasi pencegahan dan pengobatan diare

b. Metode demonstrasi atau praktek. Metode ini digunakan untuk memberikan pemahaman yang aplikatif kepada masyarakat, sehingga bisa langsung mempraktekkan untuk melindungi diri sendiri dan lingkungan, seperti membuang sampah dan mencuci tangan dengan sabun. Demonstrasi ini dilakukan atas dukungan tim pengabdian masyarakat, dan beberapa mahasiswa yang ikut serta dalam kegiatan.

\section{HASIL DAN PEMBAHASAN}

Kegiatan pengabdian akan dilaksanakan pada hari Sabtu, 27 Maret 2021 pukul 09.00 WITA sampai selesai di Masjid Ulil Amri. Kegiatan ini dilakukan dari pagi hingga siang hari, dan setiap nara sumber diisi dengan materi yang berbeda-beda. Peserta yang mengikuti kegiatan ini berjumlah 25 orang, jamaah Masjid Ulil Amri di Desa Manggala Kecamatan Manggala Kota Makassar seperti terlihat pada gambar dibawah ini:

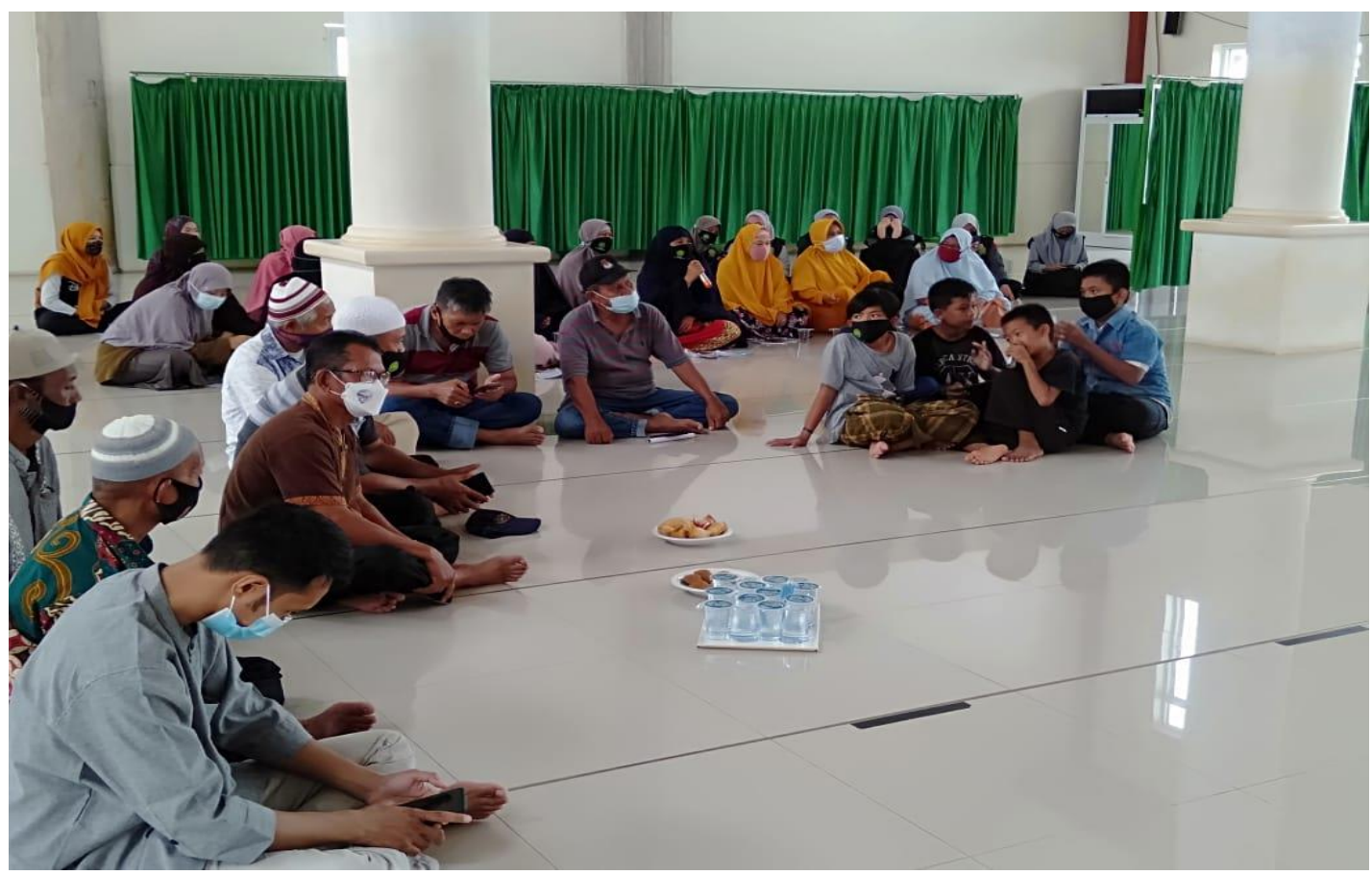

Gambar 1. Peserta Penyuluhan 
Pada pengabdian masyarakat ini juga dirangkaikan dengan kegiatan pembagian masker, handsanitizer kepada setiap peserta yang hadir mengikuti kegiatan penyuluhan serta peemasangan stand cuci tangan yang dapat dilihat pada gambar berikut;
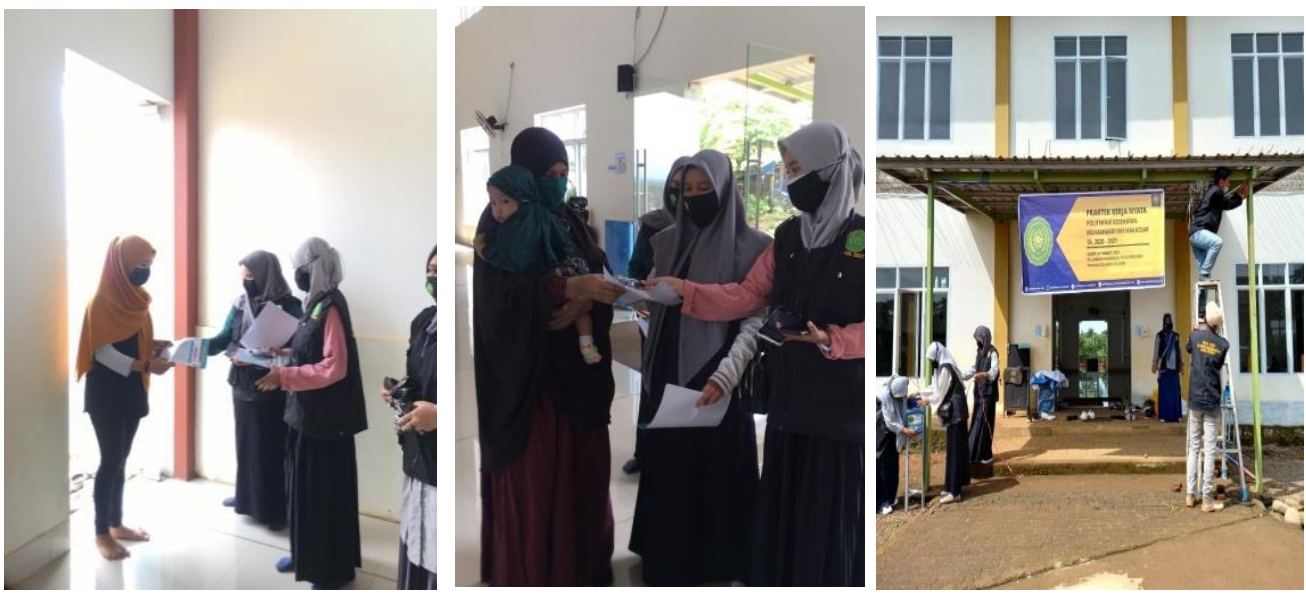

Gambar 2. Pembagian masker (a), handsanitizer (b), stand cuci tangan (c)

Peningkatan pengetahuan masyarakat melalui metode pemaparan dan demonstrasi telah menunjukkan hasil yang sangat baik. Masyarakat antusias menyimak konten yang diberikan, terlihat dari aktifnya komunitas pada panel tanya jawab, yang memberikan banyak pertanyaan, pendapat dan pengalaman yang telah digunakan untuk mencegah diare dan mengatasi serta menjaga kebersihan lingkungan.

Tujuan kegiatan pengabdian ini untuk mengenali pencegahan dan pengelolaan penjelasan diare segera penduduk pada gejala yang harus diperhatikan, dan jika warga memiliki gejala yang khas untuk segera melihat tenaga kesehatan terdekat.

Penyajian materi diare yang terdiri dari definisi diare, penyebab diare pada anak-anak, gejala dan tanda diare anak dan pencegahan dan manajemen pengelolaan diare pada anak-anak kecil dan pembuatan garam atau gula larutan garam. Metode presentase telah menggunakan konferensi interaktif, kemudian dilanjutkan dengan spanduk diare, dapat dilihat pada gambar berikut;

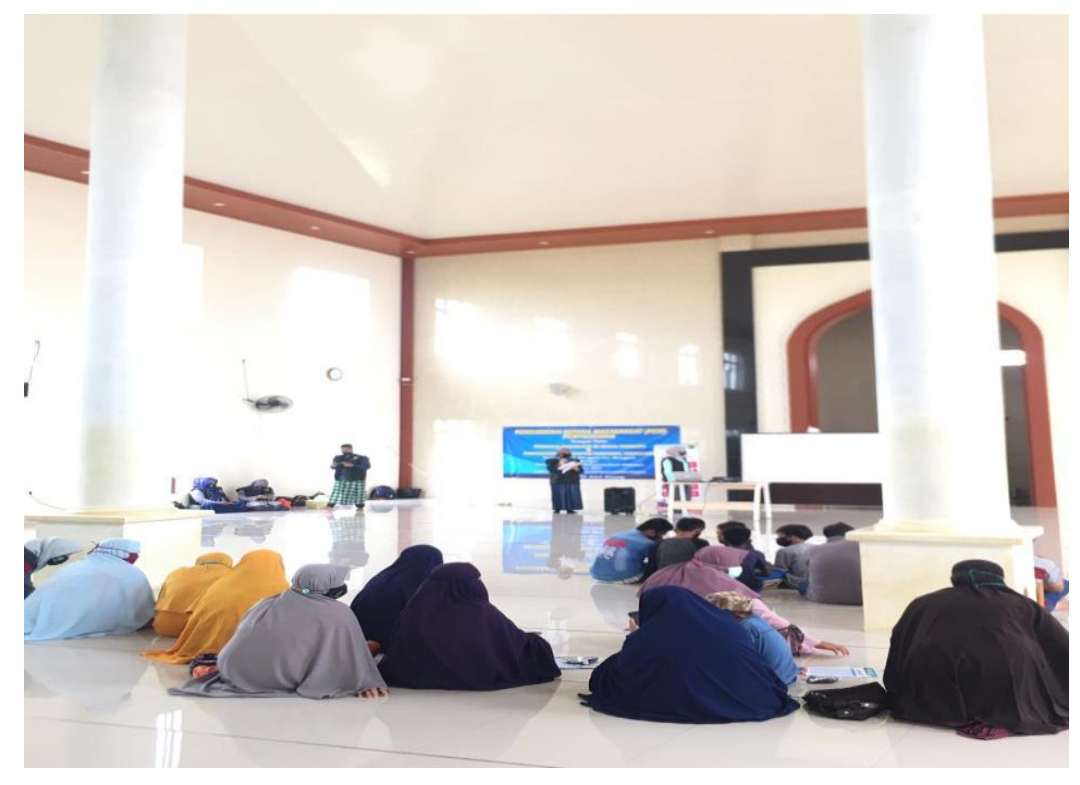

Gambar 3. Penyuluhan tentang diare 
Kegiatan mulai memberikan nasihat kepada peserta dedikasi untuk penyakit diare yang dimulai dengan definisi, gejala klinis, seperti menerapkan diagnosis, gejala berbahaya, komplikasi terburuk dan penuh kasih. Selain itu, juga dijelaskan kepada publik untuk kepentingan pengelolaan diare di rumah, serta perawatan yang memadai, dapat dilakukan segera, komplikasi lain dapat dicegah. Masyarakat juga menjelaskan kapan harus menemui dokter jika gejala diare tidak membaik. Ekstensi dilengkapi dengan brosur sehingga orang dapat lebih memahami penjelasan.

Pemberian bahan penuyluhan bahaya diare kepada ibu-ibu dan bapak-bapak jemaah mesjid Ulil Amri melalui penggunaan slide, material dan video. Selama presentasi material oleh pembicara, para peserta mendengarkan dengan antusias para peserta. Setelah narasumber selesai memberikan materi membuka forum pertanyaan dan jawaban pada materi yang disampaikan. Ada beberapa pertanyaan yang dibesarkan oleh para peserta yang dibagi menjadi dua sesi.

Metode demonstrasi yang digunakan dalam pengabdian masyarakat ini merupakan cara agar masyarakat mengetahui tentang aplikasi tersebut. Pengetahuan dan informasi terkait diabetes dan kesehatan lingkungan yang dikirim dan dipelajari oleh masyarakat dapat dikaji dan diterapkan secara kolektif. Masyarakat dapat menunjukkan cara menangani lingkungan dengan baik, seperti membuang sampah, cuci tangan pakai sabun, makan di sekitar, dan minum air yang bersih dan sehat.

Dalam acara pengabdian ini, para peserta senang dengan diskusi-diskusi reseptif yang berlangsung. Banyak peserta yang bertanya tentang penyakit cuci darah, mulai dari gejala klinis hingga komplikasi. Selain diare juga ditanyakan penyakit lain, bahkan ada beberapa peserta yang menanyakan berbagai penyakit yang diderita atau anggota keluarganya.

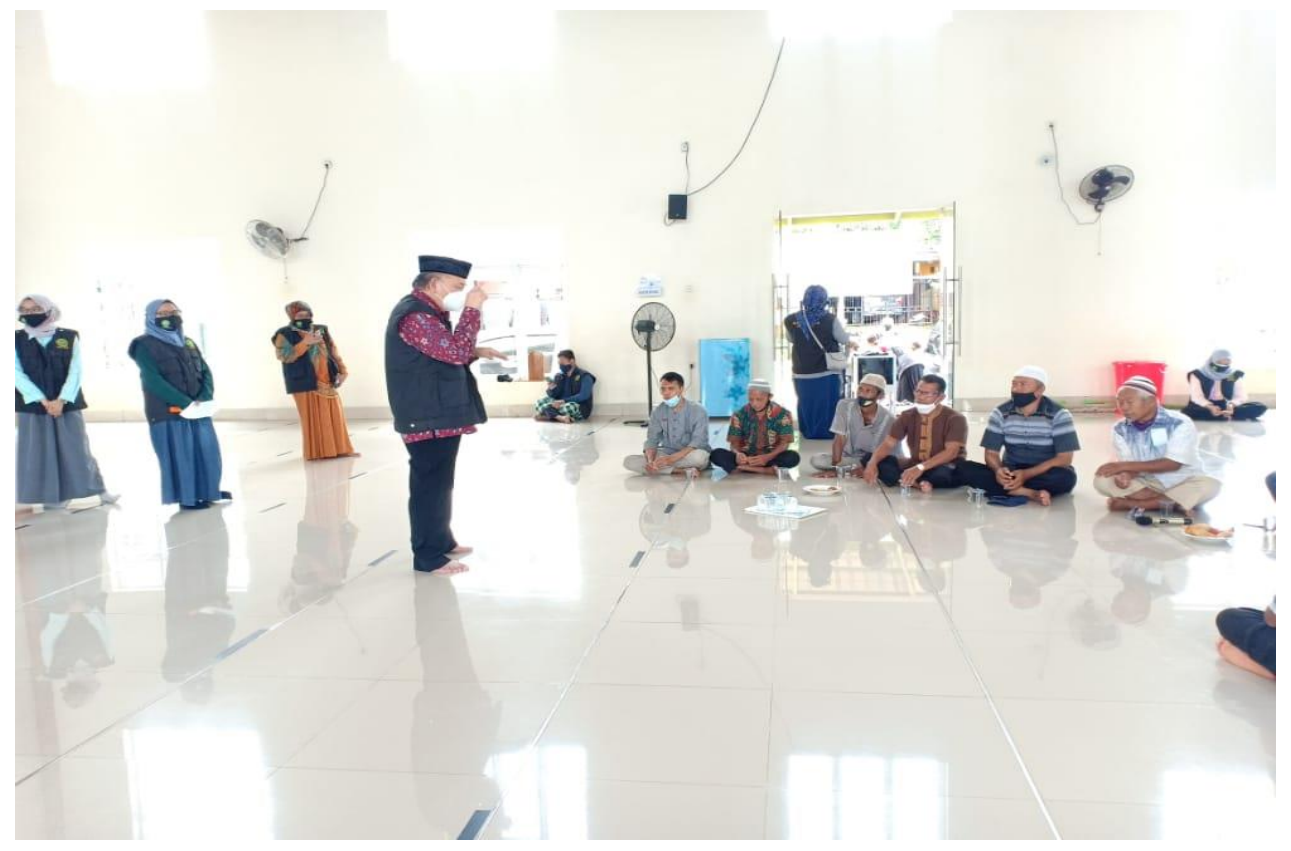

Gambar 4. Sesi tanya jawab atau diskusi dengan peserta penyuluhan

Terjadinya penyakit diare erat kaitannya dengan perilaku manusia untuk kesehatan individu dan lingkungan untuk menjaga kesehatan. Penularan penyakit diare melalui mulut yaitu air, makanan dan minuman, untuk menjaga lingkungan, perilaku dan meningkatkan pengetahuan masyarakat (Soemirat, 2014)

Akhir dari acara ini adalah kesan dan pesan dari peserta pengabdian masyarakat. Warga sangat berterima kasih atas terselenggaranya acara ini, karena warga tidak hanya puas dengan pemahamannya tentang diare, tetapi juga sangat puas dengan pemeriksaan dan konsultasi berbagai penyakit. Kegiatan pengabdian masyarakat ini juga menyediakan alat dan bahan pencegahan dan pengobatan diare di rumah berupa leaflet, hand sanitizer dan brosur. 


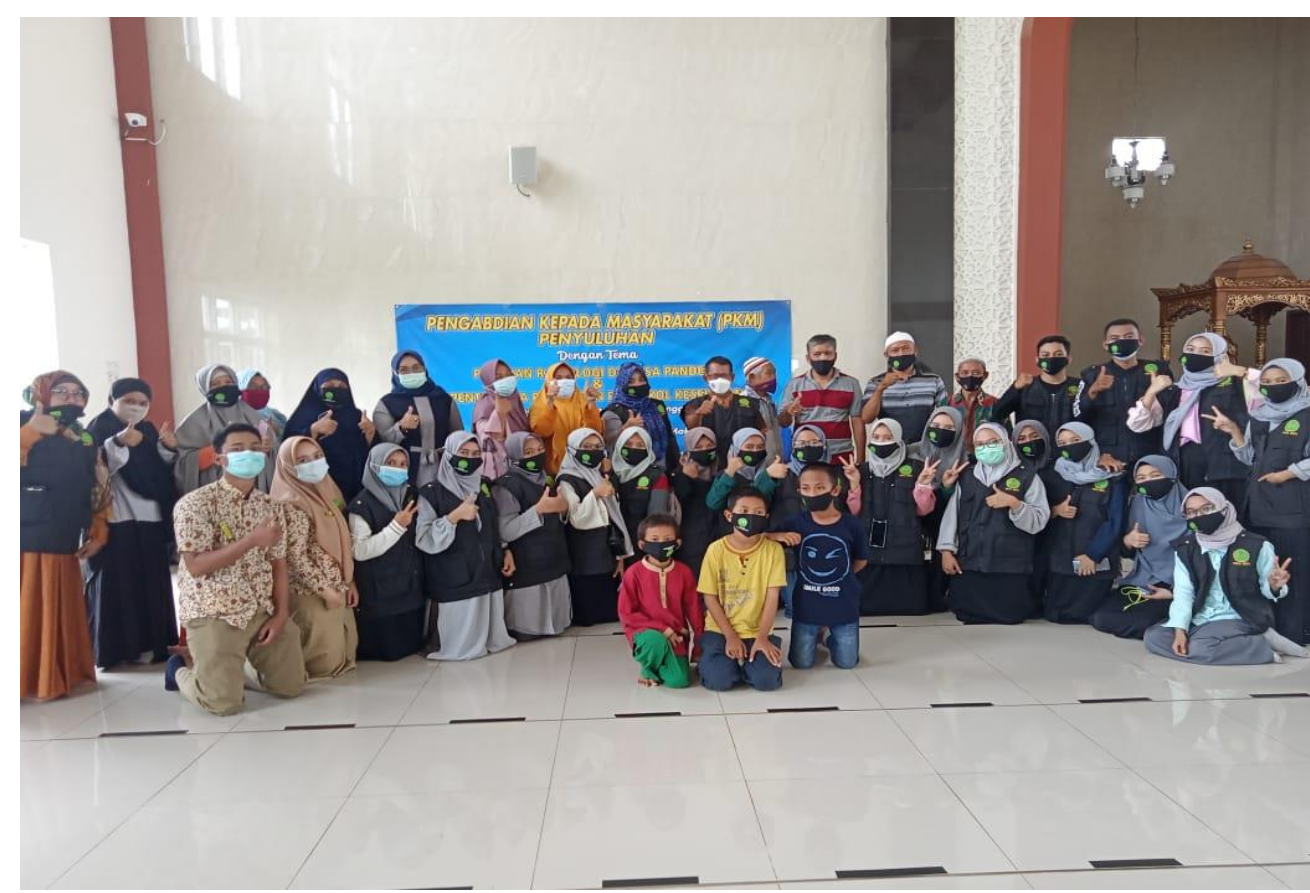

Gambar 5. Foto bersama peserta penyuluhan

Beberapa faktor yang mendukung terselenggaranya kegiatan ini adalah:

a. Peserta sangat termotivasi untuk berpartisipasi dalam semua rangkaian kegiatan dengan target peserta mencapai jumlah target peserta.

b. Banyaknya pertanyaan yang dilontarkan selama acara membuktikan antusiasme dan minat peserta yang tinggi untuk menyimak dan mengamati materi.

c. Panitia penyuluhan memberikan fasilitas untuk penyelenggaraan kegiatan.

d. Pihak Poltekkes Muhammadiyah Makassar memberikan dukungan penuh untuk mensukseskan kegiatan.

\section{KESIMPULAN}

Pengabdian masyarakat yang telah dilakukan dosen Politeknik Kesehatan Muhammadiyah Makassar pada kelompok masyarakat jemaah Mesjid Ulil Amri Kelurahan Manggala Kecamatan Manggala Kota Makassar dapat berlangsung dengan baik dan lancar sesuai jadwal yang telah direncanakan. Terlihat dari penyampaian materi dan kegiatan diskusi yang wawasan dan pemahaman peserta terjadi peningkatan.

\section{UCAPAN TERIMA KASIH}

Ucapan terima kasih disampaikan kepada Direktur, Kaprodi D3 Teknologi Laboratorium Medis, dan Lembaga Penelitian dan Pengabdian Masyarakat (LPPM) Poltekkes Muhammadiyah Makassar yang telah memberikan kesempatan dan bantuan biaya untuk pelaksanaan pengabdian kepada masyarakat, serta pemerintah Kelurahan Manggala Kecamatan Manggala Kota Makassar yang telah menyediakan sarana dan prasarana, serta kesediaan meluangkan waktu demi terlaksananya program pangabdian masyarakat.

\section{DAFTAR PUSTAKA}

Kementerian Kesehatan RI. 2011. Lima Langkah Tuntaskan Diare. Kemenkes RI. Jakarta. Kementerian Kesehatan RI. 2011. Situasi Diare di Indonesia. Kemenkes RI. Jakarta. Maryatun. 2008. Entamoeba Histolytica: Parasit Penyebab Amebiasis Usus Dan Hepar. Jurnal Kedokteran Syiah Kuala. 8(1). Pp: 39-46. 
Notoatmodjo, Soekidjo. 2010. Metodologi penelitian Kesehatan. PT. Rineka Cipta. Jakarta.

Rina. 2017. Identifikasi Protozoa Usus dan Bakteri Coliform dari Berbagai Jenis Lalat di Pasar Pasir Gintung Bandar Lampung. Universitas Islam Negeri Raden Intan Lampung. Skripsi.

Rusmartini, T. 2009. Penyakit oleh Protozoa Usus, dalam : Parasitologi edokteran Ditinjau dari Organ Tubuh yang Diserang, editor : Djaenudin Natadisastra dan Ridad Agoes. Jakarta EGC.

Soemirat, J. 2014. Kesehatan Lingkungan. 9th edn. Yogyakarta: UGM Press.

Sutanto, I., Ismid I. S., Sjarifuddin, P.K., Sungkar, S., 2011. Buku Ajar Parasitologi Kedokteran ed 4. Jakarta: Badan Penerbit FK UI.

Vivancos, V., Gonzalez-Alvarez, I., Gonzalez-Alvarez, M. 2018. Giardiasis: Characteristics, Pathogenesis And New Insights About Treatment. Curr Top Med Chem, 18(15): 1287-1303.

Wong, Donna L., et al. 2008. Buku Ajar Keperawatan Pedriatik. Cetakan pertama. Jakarta: EGC 